\title{
GPNMB wt Allele
}

National Cancer Institute

\section{Source}

National Cancer Institute. GPNMB wt Allele. NCI Thesaurus. Code C113115.

Human GPNMB wild-type allele is located in the vicinity of 7p15 and is approximately 39

$\mathrm{kb}$ in length. This allele, which encodes transmembrane glycoprotein NMB, may be involved in the modulation of cell proliferation. Aberrant expression of the gene is associated with glioblastoma multiforme and other neoplasms. 